\title{
PHYSICAL AND SOCIAL VULNERABILITY IN THE HOUSHOLD LEVEL TOWARDS TSUNAMI IN SADENG COASTAL AREA, GUNUNGKIDUL
}

\author{
Fitria Nucifera ${ }^{1}$, Sutanto Trijuni Putro ${ }^{2}$, Sakinatul Afidah ${ }^{1}$ \\ 1 Program Studi Geografi, Fakultas Sains dan Teknologi Universitas AMIKOM Yogyakarta. \\ Jl. Ringroad Utara, Condongcatur, Sleman, Yogyakarta, 55283, Indonesia \\ 2Jurusan Pendidikan Geografi, Fakultas Ilmu Sosial, Universitas Negeri Yogyakarta. \\ Jl. Colombo No. 1, Karang Malang, Sleman, Yogyakarta, 55281, Indonesia \\ e-mail: fnucifera@amikom.ac.id
}

Received: 14 July 2020, Repaired: 15 December 2020, Approved: 09 January 2021

\begin{abstract}
Tsunami occurrence in Indonesia has continued to increase until 2018. The southern coast of Java is one of the tsunami-prone areas because it is located in a subduction zone. Study location is Sadeng coastal area which is located in the south coast of DIY Province. Disaster vulnerability studies at the household level is still limited, so this paper aims to identify physical and social vulnerability to tsunami hazard at the household level. The data of this research was obtained by invterviewing household respondents and observing physical condition of building. Identification of physical vulnerability was performed using modified SCHEMA and PTVA-3 method, while social vulnerability assessment considered demographic and socio-economic parameters. Total vulnerability was retrieved from matrix analysis of physical and social vulnerability classification. The study shows that 64 $\%$ households in Sadeng coastal areas are classified to moderate vulnerability, 30\% of households are high vulnerability and $6 \%$ of households are low vulnerability. High vulnerability is characterized by households which occupy non-permanent houses, have no economic assets, and have a high dependency ratio. Moderate vulnerability is characterized by households which occupy semi-permanent house, have economic assets, but have high dependency ratio. Low vulnerability is characterized by households which live in government-owned buildings, have economic assets, and have low dependency ratio.
\end{abstract}

Keywords: tsunami, vulnerability, building `s physical vulnerability, social vulnerability

\begin{abstract}
Abstrak
Kejadian tsunami di Indonesia terus mengalami peningkatan hingga tahun 2018. Pesisir selatan Jawa merupakan salah satu kawasan yang terpapar bahaya tsunami karena terletak pada zona subduksi. Lokasi kajian adalah kawasan pesisir Sadeng yang berlokasi di pesisir selatan Propinsi DIY. Kajian kerentanan bencana di tingkat rumah tangga belum banyak dilakukan, sehingga tulisan ini bertujuan untuk melakukan identifikasi kerentanan fisik bangunan dan sosial terhadap bencana tsunami di tingkat rumah tangga. Perolehan data penelitian dilakukan dengan wawancara responden rumahtangga dan observasi kondisi fisik bangunan. Identifikasi kerentanan fisik bangunan dilakukan dengan metode SCHEMA dan PTVA-3 yang dimodifikasi, sedangkan penilaian kerentanan sosial mempertimbangkan parameter kependudukan dan sosial ekonomi. Nilai total kerentanan diperoleh dari analisis matriks klasifikasi kerentanan sosial dan fisik bangunan. Kajian menunjukkan bahwa sebesar 64 \% rumahtangga di kawasan pesisir Sadeng termasuk dalam kelas kerentanan sedang, $30 \%$ rumahtangga dalam kerentanan tinggi dan $6 \%$ rumahtangga dalam kerentanan rendah. Tingkat kerentanan tinggi dicirikan dengan rumahtangga yang menempati rumah tinggal non-permanen, tidak memiliki asset ekonomi, dan memiliki angka ketergantungan yang tinggi. Tingkat kerentanan sedang
\end{abstract}


dicirikan dengan rumahtangga yang menempati rumah tinggal semi permanen, memiliki asset ekonomi namun memiliki angka ketergantungan yang tinggi. Tingkat kerentanan rendah dicirikan dengan rumahtangga yang tinggal pada bangunan milik pemerintah, memiliki asset ekonomi, dan memiliki angka ketergantungan yang rendah.

Kata kunci: tsunami, kerentanan, kerentanan fisik bangunan, kerentanan sosial

\section{INTRODUCTION}

Indonesian geographic position leads it prone to geologic and hydrometeorological disaster. The increasing number of disaster frequency resulting a large loss in many aspects of live. The high losses were caused by the high population and its surrounding environmental vulnerability (Shah, Ye, Abid, Khan, \& Amir, 2018). Tsunami is a seawave triggered by under-sea earthquake, landslide, even undersea volcanism
(Cartwright \& Nakamura, 2008). Some devastating mega tsunamis with high loss were: Indian Ocean tsunami in 2004, Chile in 2010, and Tohoku in 2011 (De Risi \& Goda, 2017).

Tsunami occurrence in Indonesia is rising recently. Since before 1600 up to 2018, there were 248 tsunami events in Indonesia (BMKG, 2019). 25 events occurred in Java coast in those time. The hight occurrence happened between 1900-1999 with 106 occurences (see Figure 1).

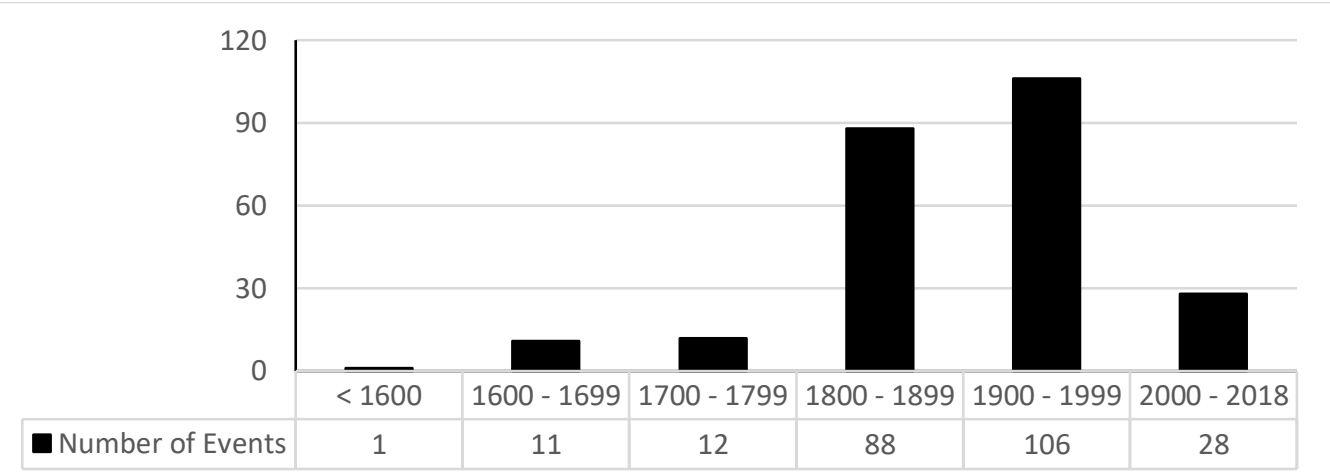

Figure 1. Number of Recorded Tsunami Events in Indonesia since 418 - 2018 (BMKG, 2019)

Tsunami that occurred in Java, were triggered by earthquake in quake and subduction zone inside back-arc thrusting earthquake (Hamzah, Puspito, \& Imamura, 2000). Tsunami in Java only covering approximately only $10 \%$ of total tsunami occurrence in Indonesia with death toll reach $6 \%$ of total in Indonesia (BMKG, 2019). If compared to different area in Indonesia, tsunami in Java relatively less than the other area in Indonesia. However, it can not be ignored since Java is the most populated island in Indonesia (Sunarto et al., 2010).

Coastal area in southern Java is highly prone to tsunami (Marfai et al., 2008). This condition implicates to the high of loss and impace to the surrounding area. One of disaster parameters commonly used to describe and drive the risk potential due to hazard exposure is vulnerability (Adger, 2006; Bakkensen, Fox-Lent, Read, \& Linkov, 2017; Linkov et al., 2014). In order to reduce the risk, the most possible parameter to modified is vulnerability as indicated in several studies (Birkmann et al., 2015; J. León \& March, 2016).

Vulnerability is defined as potential threat to human and their surrounding environment as the result of disaster hazard which include physic, social, economy, and environmental aspects (UNISDR, 2009). Assessment on community and environmental vulnerability enables society to recognize their vulnerability level in order to increase emergency effort when facing disaster event (Dong Keun Yoon \& Jeong, 2016). 
Vulnerability level depends on many things, as an overvies, as studied in China, social/population vulnerability is depends on rural character, development, and economic status (Zhou, Li, Wu, Wu, \& Shi,
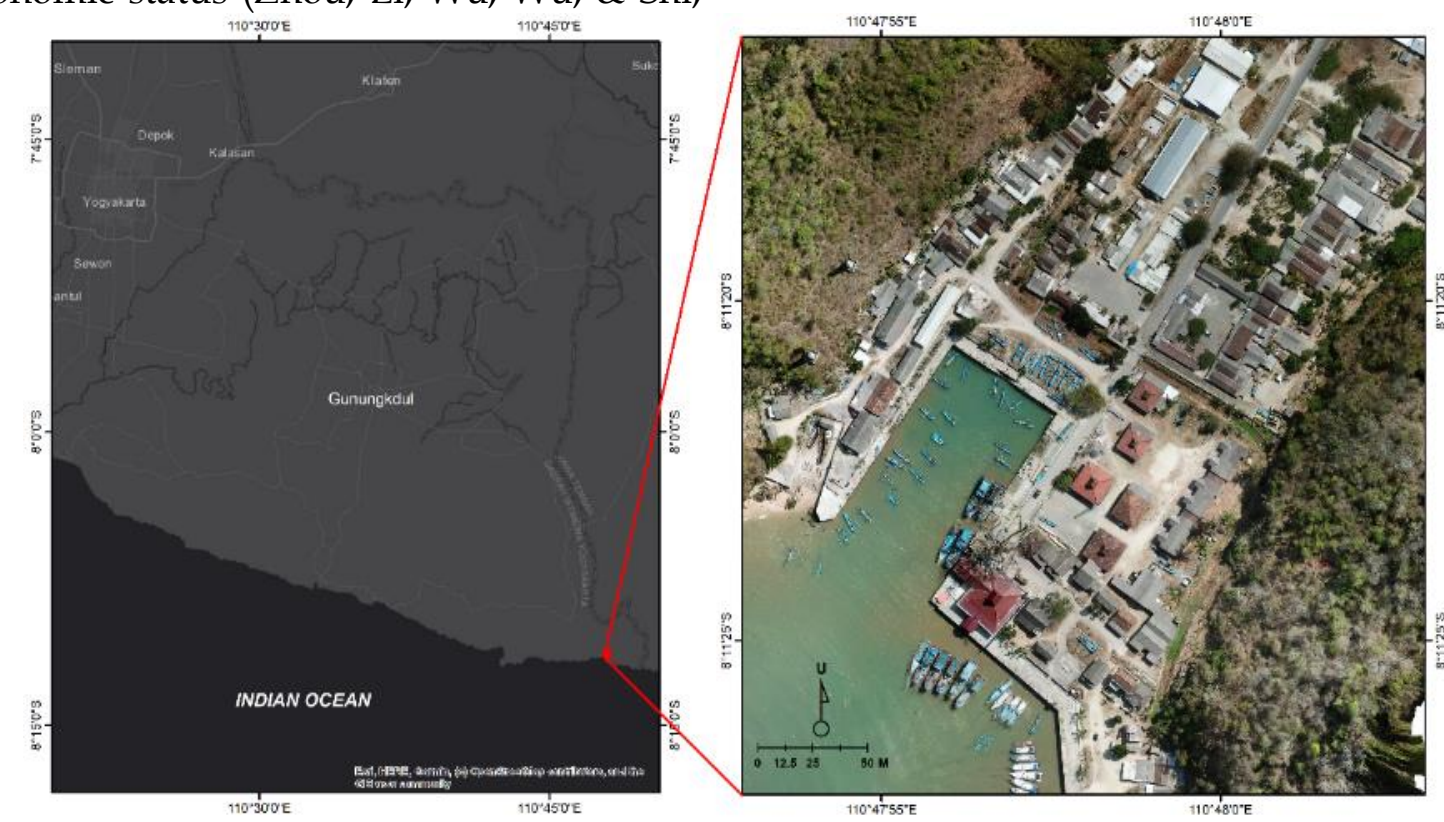

Figure 1. Study area inzet of Gunungkidul Regency (left), Sadeng Port (right)

This study focused on the identification of physical and social vulnerability in facing tsunami hazard in the household level. Household is the smallest unit in social community structure. Houshold has the most important role in reducing disaster risk (Aerts et al., 2018; Shapira, Aharonson-Daniel, \& Bar-Dayan, 2018). Each household posess unique vulnerability parameters that make them distinct to others.

Physical parameters considers buildings and structures characteristics such as building materials, size, number of floors, and the age of the building (McEntire, 2011; D. K. Yoon, 2012). In many disaster events, building become the most vulnerable (Wibowo et al., 2017). Damaged building and man-made structure will cause secondary hazard for the people (Chiaro et al., 2015), yet structures and building will affected the tsunami wave behavior and propagation (Moon et al., 2019; Tomiczek, Prasetyo, Mori, Yasuda, \& Kennedy, 2017).

Social vulnerability related to demographic and community economy profile (Cutter et al., 2003). People with toddler and elderly age, low income and
2014). As general, marginal community with social and economical limitation tends to have a higher vulnerability in facing disaster events (Jeong \& Yoon, 2018).

education, and minorities will be more vulnerable to disasters (McEntire, 2011; D. K. Yoon, 2012). In 2011 tsunami following an earthquake in Tohoku, Japan, more than $60 \%$ of fatalities were older than 60 years old (Hagiwara, Miyake, Nakasu, Ono, \& Sawai, 2011) in (Sawai, 2011).

Sadeng Coastal Area is a minapolitan (business center based on fishery), administratively part of Gunungkudul

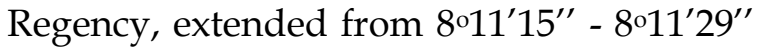
South and 110 $47^{\prime} 55^{\prime \prime}$ - 110 $48^{\prime} 05^{\prime \prime}$ East (Figure 2). Most of the resident built from fisherman household, immigrant from outside of Sadeng (Nucifera, Riasasi, Putro, \& Marfai, 2019). This area consists of port supporting infrastructures and fisherman settlement.

This study was conducted to identify the building as the parameter for physical vulnerability and assess the social vulnerability in facing tsunami with the level analysis on household scale. Fishermen household physically and socially will be related to vulnerability due to tsunami event. Assessment on household vulnerability will provide detail information 
for a proper disaster risk reduction effort in household scale

\section{METHOD}

This study implemented a quantitative method through calculation of physical and social vulnerability index. The main data used in this study was interview data along with field observation, complemented with aerial photograph of the study area (Table 1). Unit of analysis used was household with samples taken by proportional random sampling resulted in 70 households were taken in this study.

Table 1. Parameters in this study

\begin{tabular}{ll}
\hline \multicolumn{1}{c}{ Data type } & Assessment method \\
\hline $\begin{array}{l}\text { Demographic and } \\
\text { socio-economic data }\end{array}$ & Interview \\
$\begin{array}{l}\text { Building physical } \\
\text { condition }\end{array}$ & Observation \\
$\begin{array}{l}\text { Aerial photograph of } \\
\text { the study area }\end{array}$ & $\begin{array}{l}\text { UAV (unmanned } \\
\text { aerial vehicle) survey }\end{array}$ \\
\hline
\end{tabular}

Physical vulnerability assessment was focused on building used as settlement and center of activity. Social vulnerability assessment was focused on demograpic aspect and economic assets. Visual observation technique was used to assess the building condition, while economy vulnerability variable data acquired by interview using semi-closed questionnaire.

\section{Physical Vulnerability}

Parameters considered in building`s physical vulnerability are number of floors, main building material, roof material, type of construction, hydrodynamics of building floors, and building orientation (Dall Osso, Gonella, Gabbianello, Withycombe, \&
Dominey-Howes, 2009; Tinti et al., 2011). This study utilized modified SCHEMA (SCenarios for tsunami Hazard-induces Emergencies MAnegement) Project and revised PTVA-3 (Papathoma Tsunami Vulnerabillity Assessment version 3) for building classification. SCHEMA Project is focused on building strength and damage potential due to tsunami, based on posttsunami building physical condition and damage database in mega tsunami event in 2004 (Valencia et al., 2011). Revised PTVA-3 method generally considers building vulnerability based on its structure vulnerability and vulnerability of the building during contact with water (Dall Osso et al., 2009). Parameters for building`s physical vulnerability represented in Table 2.

Main materials and type of the structure plays an important role to the building`s tsunami resistance (Papathoma and Howes, 2003). Reinforced concrete with double brick masonry is the most resistant structure for tsunami (Dall 'Osso et al., 2009). Building that built mainly of wood has the lowest resistance, means it has the high vulnerability to tsunami (Dall Osso et al., 2009; Reese et al., 2007; Tinti et al., 2011). The weak structure and main material of a building will drive the building damage potential is higher (Wibowo, Mardiatno, \& Sunarto, 2017). Building with open space or open plan tends to have lower damage due to more space available to reduce the waveforce (Dall Osso et al., 2009; Dalrymple \& Kriebel, 2005). Scoring for building`s physical vulnerability is presented in Table 2.

Table 2. Building`s Physical Vulnerability Parameters

\begin{tabular}{|c|c|c|}
\hline Parameters & Description & Score \\
\hline \multirow{3}{*}{$\begin{array}{l}\text { Main building } \\
\text { material, } \\
\text { construction } \\
\text { type, type of } \\
\text { roof truss, } \\
\text { number of floors }\end{array}$} & $\begin{array}{l}\text { Light construction building: Nearshore } \\
\text { building with wooden materials, single floor }\end{array}$ & 25 \\
\hline & $\begin{array}{l}\text { Light construction building: very light } \\
\text { construction, without design, built with clay } \\
\text { and iron sheeting, single floor }\end{array}$ & 25 \\
\hline & $\begin{array}{l}\text { Stone construction building: Brick masonry } \\
\text { with mortar, 1-2 floors }\end{array}$ & 20 \\
\hline
\end{tabular}




\begin{tabular}{|c|c|c|}
\hline \multirow{7}{*}{$\begin{array}{l}\text { Parameters } \\
\text { (Tinti et al., } \\
\text { 2011) }\end{array}$} & Description & Score \\
\hline & $\begin{array}{l}\text { Stone construction building: Light } \\
\text { construction, consentrated with wood and } \\
\text { clay }\end{array}$ & 20 \\
\hline & $\begin{array}{l}\text { Stone construction building: Main material } \\
\text { with reinforced column and mortared bricks, } \\
\text { 1-2 floors }\end{array}$ & 15 \\
\hline & $\begin{array}{l}\text { Bangunan konstruksi batu terbuat dari batu } \\
\text { kali yang berselingan dengan batu bata, 1-2 } \\
\text { lantai }\end{array}$ & 15 \\
\hline & $\begin{array}{l}\text { Stone construction building: grouped } \\
\text { building, offices complex, school, } \\
\text { unreinforced concrete, 1-3 floors }\end{array}$ & 10 \\
\hline & $\begin{array}{l}\text { Stone construction building: grouped } \\
\text { building, offices complex, school, reinforced } \\
\text { concrete with steel frame, 1-3 floors }\end{array}$ & 5 \\
\hline & $\begin{array}{l}\text { Reinforced concrete construction: group } \\
\text { buildings, office complexes, schools, using } \\
\text { reinforced concrete and steel frames, more } \\
\text { than } 3 \text { floors }\end{array}$ & 5 \\
\hline \multirow{3}{*}{$\begin{array}{l}\text { Hydrodynamics } \\
\text { of building } \\
\text { floors (Dall'Osso } \\
\text { et al., 2009) }\end{array}$} & Building with open plan & 1 \\
\hline & $\begin{array}{l}\text { Building with } 50 \% \text { open plan with windows } \\
\text { and doors }\end{array}$ & 3 \\
\hline & Building with no open plan & 5 \\
\hline \multirow{3}{*}{$\begin{array}{c}\text { Building } \\
\text { orientation to } \\
\text { coastline } \\
\text { (Dall'Osso et al., } \\
2009 \text { ) }\end{array}$} & Perpendicular to coastline & 1 \\
\hline & Angled to coastline & 3 \\
\hline & Parallel to coastline & 5 \\
\hline
\end{tabular}

Source: Tinti et al., 2011; Dall'Osso et al., 2009 with modification

\section{Social Vulnerability}

Assessment of social vulnerability is aims to determine the tendency of affected coastal community to tsunami inundation (UNESCO, 2015). Assessment parameter for social vulnerability is presented in Table 3. Number of family member is one of the parameters in social vulnerability. The more family members, especially the elderly and toddlers, tend to have higher vulnerability due to the lack of resources to support the family (Cutter, Boruff, \& Shirley, 2003; Dong Keun Yoon \& Jeong, 2016). Therefore, the dependency ratio is included in the vulnerability parameter. During the 2004 Indian Ocean tsunami, the number of victims tended to be higher in the toddler and elderly age groups (J. C. V. de León, 2008).

Economic vulnerability is related to losses incurred by the tsunami disaster. Losses due to the 2004 Indian Ocean tsunami consisted of $60 \%$ direct losses (physic and infrastructure damage) and $40 \%$ indirect losses (decreased economic activity) (Athukorala \& Resosudarmo, 2005). The existence of assets in a household in terms of the economy becomes important in postdisaster recovery efforts as well as from a disaster risk perspective (Hizbaron, Hadmoko, Samodra, Dalimunthe, \& Sartohadi, 2010). 
Table 3. Social Vulnerability Parameters

\begin{tabular}{ccc}
\hline Parameters & Description & Score \\
\hline \multirow{2}{*}{ Number of family } & $\leq 2$ people & 1 \\
member & $3-4$ people & 2 \\
& $5-6$ people & 3 \\
& $>6$ people & 4 \\
\hline \multirow{2}{*}{ Number of toodler in the } & $1-2$ people & 1 \\
family & $3-4$ people & 2 \\
& $>4$ people & 3 \\
\hline \multirow{2}{*}{ Number of elder in the } & $1-2$ people & 1 \\
family & $3-4$ people & 2 \\
& $>4$ people & 3 \\
Number of family & $1-2$ people & 1 \\
member in special need & $>2$ people & 2 \\
\hline Dependency ratio & $<50$ & 1 \\
& $50-100$ & 2 \\
& $100-200$ & 3 \\
Assets ownership & $>200$ & 4 \\
& Fixed and current assets & 1 \\
& Fixed assets & 2 \\
& Current assets & 3 \\
\hline
\end{tabular}

Source: Cutter et al., 2003; Hizbaron et al., 2010; Yoon and Jeong, 2016 with modification

\section{Total Vulnerability}

The total vulnerability is determined based on the physical vulnerability class and social vulnerability. Physical and social vulnerabilities were classified using the standard deviation method. The standard deviation method is widely used in the spatial data classification by considering the standard deviation value and the average value as a differentiator for the attribute values of each class. (Osaragi, 2002) (Table 4). The total vulnerability class is determined based on a vulnerability matrix, see Figure 2 .

Table 4. Physical and Social Vulnerability

\begin{tabular}{|c|c|}
\hline \multicolumn{2}{|c|}{ Classification } \\
\hline Class & Description \\
\hline High & $\begin{array}{c}>\text { (mean value }+ \text { standard } \\
\text { deviation })\end{array}$ \\
\hline Medium & $\begin{array}{c}\text { (mean value - standard } \\
\text { deviation) }-(\text { mean value }+ \\
\text { standard deviation })\end{array}$ \\
\hline Low & $\begin{array}{c}<\text { (mean value }- \text { standard } \\
\text { deviation })\end{array}$ \\
\hline
\end{tabular}

Source: Osaragi (2002)

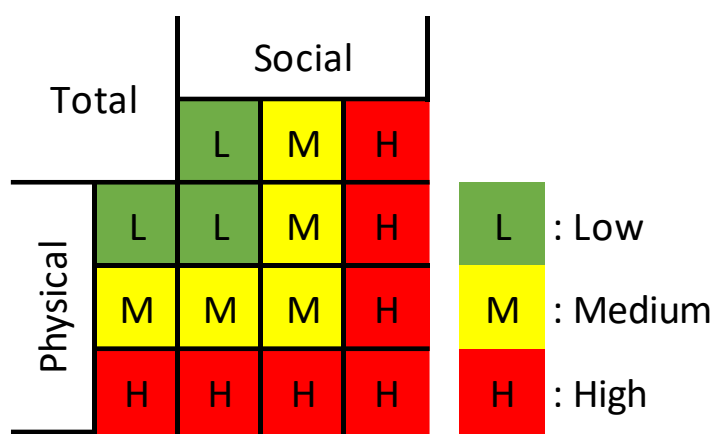

Figure 2. Vulnerability matrix

\section{RESULTS AND DISCUSSION}

The results of the study include three aspects that are physical vulnerability, social vulnerability, and total vulnerability. For each values of vulnerability were classified into high, medium, and low class of vulnerability.

\section{Social Vulnerability}

Social vulnerability parameters include demographic and economic parameter. The demographic parameter is related to the population exposed by tsunami, especially vulnerable group. As 


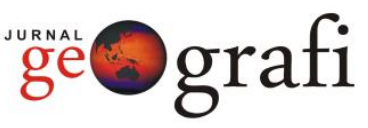

much as $57 \%$ respondents have 4 family members and $23 \%$ of respondents have 5 family members (Figure 3). Based on this result, people in Sadeng coastal area tend to have more family members. The more family members, the more vulnerable to disaster (Cutter et al., 2003).

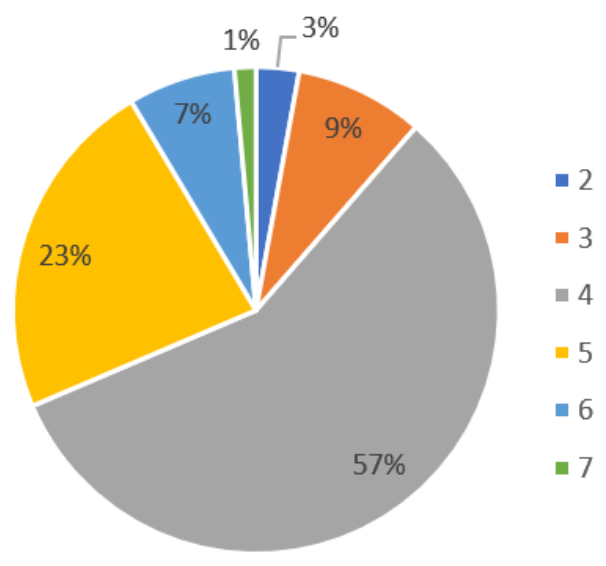

Figure 3. Number of family members (Source: Data analysis, 2020)

Households with children under five years and the elderly tend to be more vulnerable to disaster (UNESCO, 2015; Yang, He, Du, \& Sun, 2015). Children under five years and the elderly have a dependency on others during the tsunami evacuation. The overall percentage of vulnerable groups is $17 \%$ of the total population of 299 people (Figure 4). The number of vulnerable groups in Sadeng coastal area is relatively low. This area is dominated by fishermen in productive age. Most of the people have not been living with the main family because this area is not good enough for children development. The lack of health and education facilities is one of the reasons for people to not live with their main family. Even a few of them live nomadically according to the fishing season. The number of fishermen will be increased in the fishing season. These fishermen come from the outside of Sadeng such as Cilacap, Surabaya, Banyuwangi to Sulawesi (Nucifera et al., 2019). Another vulnerable group is people with disabilities or special needs. This area does not have people with disabilities, so the value in this parameter is assumed to be 0 .

Dependency ratios describe the capacity response of a community to cope with a crisis (Gregory, Johnston, Pratt, Watts, \& Whatmore, 2009). The dependency ratios represent the number of people of productive age who support the needs of children and the elderly (Stăngă \& Grozavu, 2012). More than $50 \%$ of households prove a high dependency ratio valued between 100-200 \% (Figure 5). High dependency ratio (more than 100\%) indicates that the number of dependents people in a household is greater than the number of productive people. The burden of people in productive age will be greater because of the number of dependents people in the household. During the disaster, this typical household will be more difficult to recover the economy.

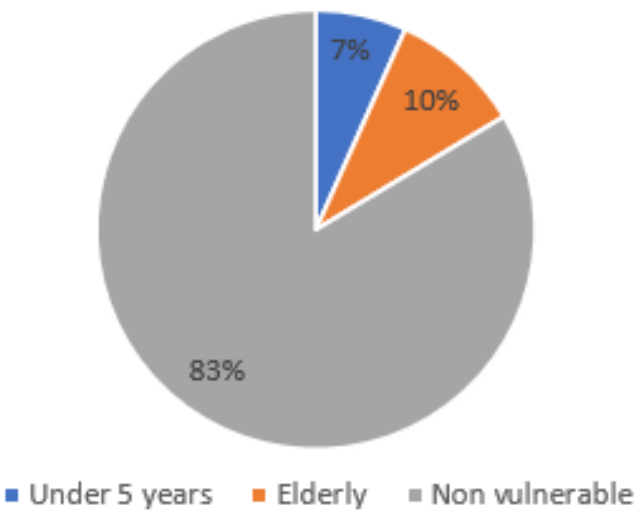

Figure 4. Percentage of vulnerable group to unvulnerable group (Source: Data analyis, 2020)

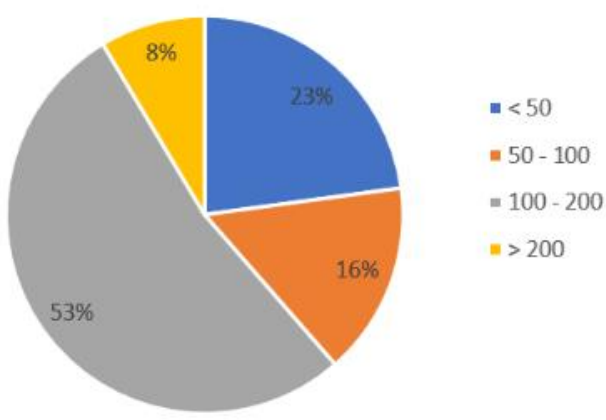

Figure 5. Percentage of dependency ratio

(Source: Data analysis, 2020)

Economic parameter was focused on the asset's ownership in the household. Asset ownership will be helpful for postdisaster recovery process (Vatsa, 2004). 


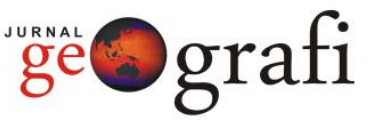

Fixed assets are more valuable than current assets in terms of post-disaster recovery. Fixed assets include land, building, and gold which can be utilized as post-disaster resources. Current assets include stock, short-term deposits, and vehicles. Most of households (90\%) owned current assets such as motorcycle and fishing boat (Figure 6). Current assets are more likely to be damaged during the tsunami. Motorcycle and fishing boat can be lost or damaged due to the tsunami waves. On the other hand, fixed assets tend to be more valuable over time. Households of this area dominantly live in the portland area belongs to the provincial government. They pay rent for living in this area. A few households owned their private property in this area. Based on these data, it can be concluded that
DOI: 10.24114/jg.v\%vi\%i.19160 e-ISSN: 2549-7057 | p-ISSN: 2085-8167

households living in this area are classified as low economic capability.

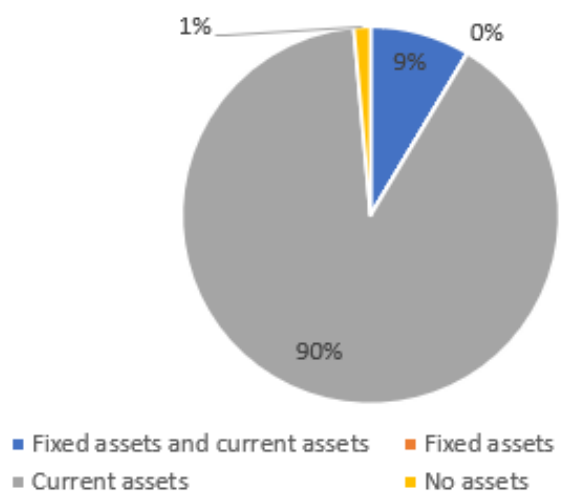

Figure 6. Percentage of asset ownership (Source: Data analysis, 2020)

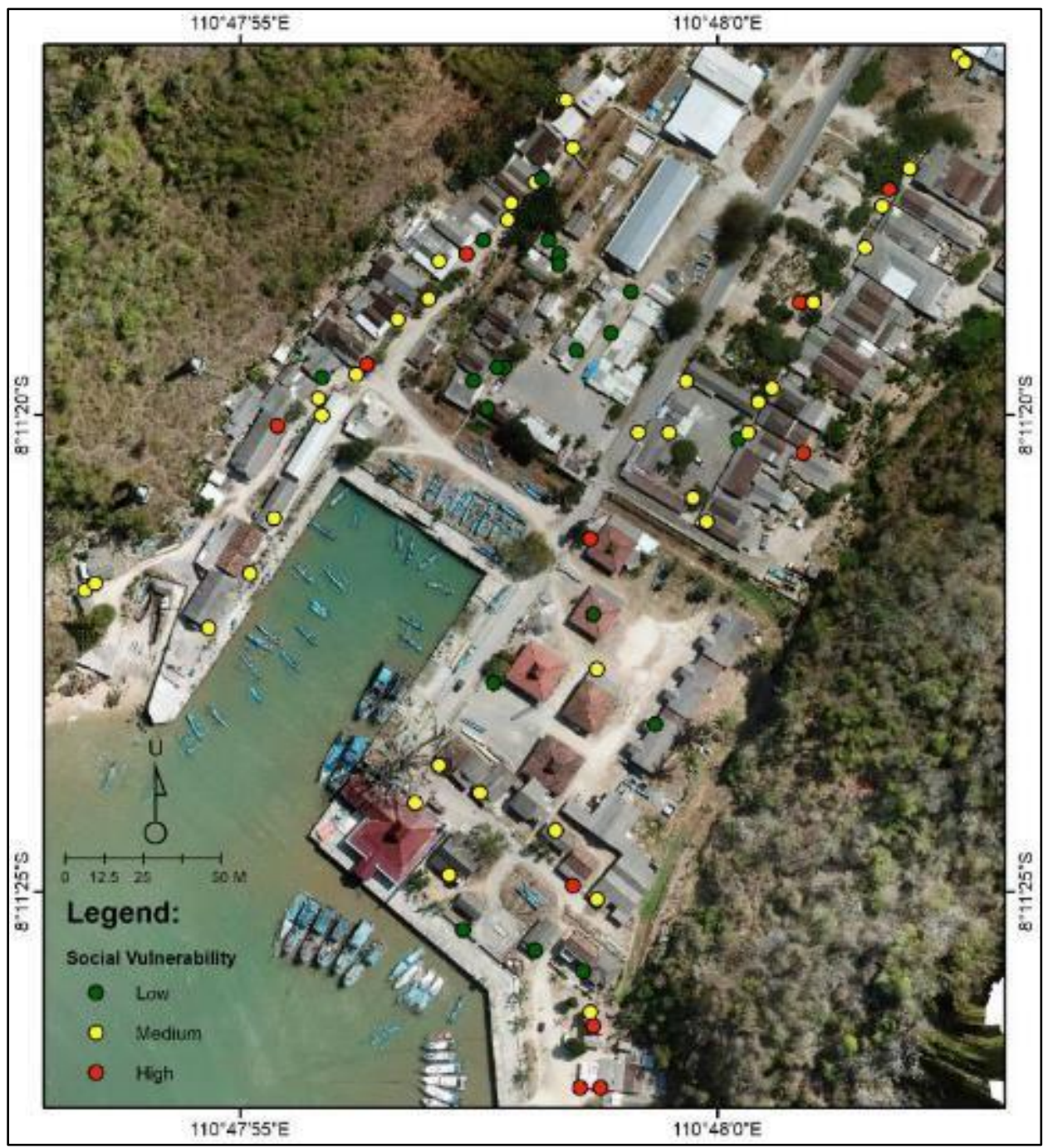

Figure 7. Spatial distribution of social vulnerability

(Source: aerial photograph survey, 2019) 
Spatial distribution of social vulnerability is described in Figure 7. Social vulnerability was classified as high, medium, and low vulnerability. As much as $44 \%$ of households were classified as medium vulnerability, $34 \%$ of households were classified as high vulnerability, and 21 $\%$ of households were classified as low vulnerability. Some high vulnerability households were clustered in the eastern part of the port. High vulnerability households dominantly affected by high dependency ratio and low assets ownership. Low asset ownership caused low economic capability to build back better. A high dependency ratio in households also resulted in unstable economic conditions. Improving the economic condition in households will be the one of solutions to reduce social vulnerability. Several strategies to improve the economic conditions include livelihood diversification and financial management for households. Thus far, household's economic condition has been depending on fisheries. Livelihood diversification provides opportunities for households to earn income from other sectors than fisheries. Financial management is expected to encourage households to own the fixed assets.

\section{Physical Vulnerability}

Sadeng coastal area is in a narrow bay and flanked by the hills from the Ancient Bengawan Solo river. The narrow area sized approximately 8,7 hectares is divided into a port area and settlements area. Port areas include office area, docking area, loading area, and industrial area. Industrial area consists of fishing auction and ice factory. Port area and settlements area have different building characteristics. Port area was built by the government according to building engineering design. Most of the buildings in this area were built using masonry and a strong foundation. Meanwhile, settlements areas were built by the community as semipermanent buildings.

Infrastructure as a vulnerability parameter is divided into exposure and sensitivity of infrastructure (Aguirre-Ayerbe et al., 2018) which was modified by Nucifera, Riasasi, Putro dan Marfai (2019) according to the

Table 2. Buildings have an impact both reducing and increasing risk (AguirreAyerbe et al., 2018; González-Riancho et al., 2014). Damaged infrastructure exacerbated tsunami impact in Aceh during the Indian mega-tsunami 2006. The damaged infrastructure has resulted in limited access, slow recovery, logistic supply disruption, and information disturbance (Ghobarah, Saatcioglu, \& Nistor, 2006), and has even led to increase casualties (Lindell \& Prater, 2003).

Infrastructures in Sadeng coastal area functioned as strategic, public, emergency, electricity supply, water resource, and fuel infrastructure (Nucifera et al., 2019), in more detail is shown in

Table 24. The existence of these infrastuctures give an impact socially and economically to the households. The losses of valuable assets both settlements and business places, resulted in economic losses for households. The severity of tsunami impact varies among the households depending on the physical and socioeconomic condition. Disaster does not affect the households to the same extent, households with lower economic capability will be more affected due to the disaster (Chmutina \& von Meding, 2019; O'Brien, O'Keefe, Rose, \& Wisner, 2006; Wisner, Blaikie, Cannon, \& Davis, 2004).

Table 2. Infrastructures in Sadeng coastal area

\begin{tabular}{cl}
\hline \multicolumn{1}{c}{ Type of infrastructure } & \multicolumn{1}{c}{ Infrastucture's name } \\
\hline Strategic infrastructure & Fishing port \\
& Fishing auction \\
& Early warning system (EWS) and tidal stations
\end{tabular}




\begin{tabular}{|c|c|}
\hline Type of infrastructure & Infrastucture's name \\
\hline & Port office \\
\hline Public infrastructure & $\begin{array}{l}\text { Mosques, public toilet, parking area, fish } \\
\text { market, food stalls }\end{array}$ \\
\hline \multirow[t]{4}{*}{ Emergency infrastructure } & Search and Rescue office (POS SAR Satlinmas \\
\hline & DIY) \\
\hline & Safety Monitoring Post (Poswaskespel) \\
\hline & Water Police office (DIT. POLAIR) \\
\hline \multirow{3}{*}{$\begin{array}{l}\text { Electricity supply, water, } \\
\text { and fuel }\end{array}$} & Fuel station (SPBU Sadeng) \\
\hline & Artesian well \\
\hline & Powerhouse \\
\hline
\end{tabular}

(Nucifera et al., 2019)

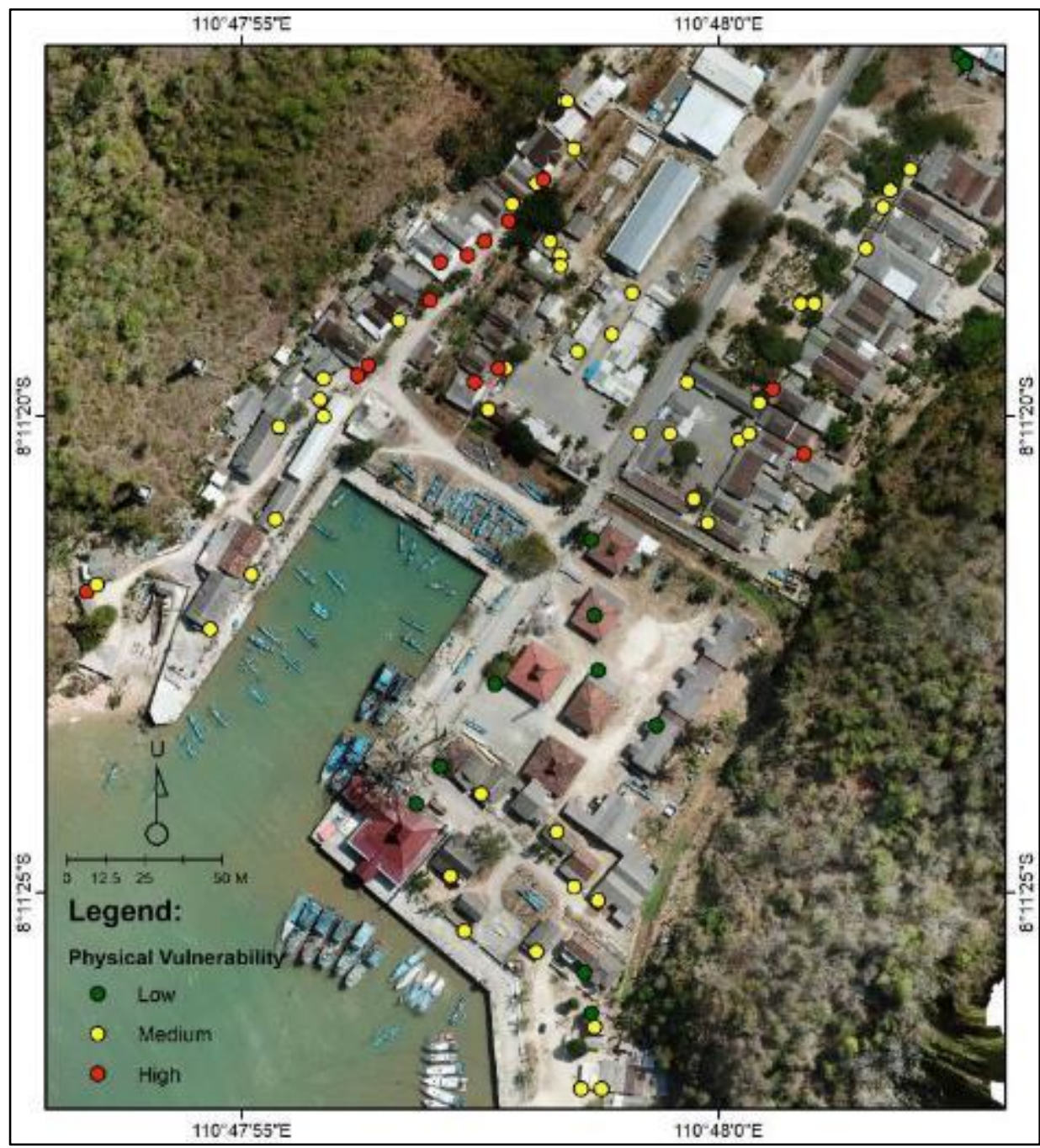

Figure 8. Spatial distribution of physical vulnerability in Sadeng coastal area

Physical vulnerability was determined by the building's characteristics according to the scoring of building's physical vulnerability parameter. From the field survey, it showed that buildings in Sadeng coastal area were not homogeneous.
Generally, permanent buildings were dominantly part of the port infrastructure and its supporting facilities. Semipermanent and non-permanent building were built by households living in this area. 
Spatial distribution of physical vulnerability is showed in Figure 8. Most of the buildings with low vulnerability were insfrastuctures built by government which functioned as an office and administration. The buildings were made of masonry, structured columns, and well maintained. These buildings are located on the southeast side of port area.

On the west part of Sadeng coastal area, there is a row of warehouses followed by settlements of fishermen. Warehouses were built by government. These buildings had a lot of damage, so it caused increasing the potential threat to the people around. Lack of building maintenance due to lack of finance and capacity will increase disaster risk (United Nations, 2015). The issues of building and infrastructure maintenance are considered as an important issue regarding disaster risk reduction. Until 2015, it started to make a program to increase awareness of building maintenance which were initiated in Japan (United Nation, 2015).

Most of buildings with high vulnerability are located outside the port area. These buildings belong to the fishermen for housing and business places. Due to the weakness of building materials to cope with the tsunami waves, these buildings were classified as highly vulnerable. The buildings were dominantly made by wood and plywood (FigureFigure 9). Plywood as the main material in the building can not survive when the tsunami waves hit the buildings, so the people living in this kind of buildings must be evacuated immediately after a tsunami warning comes (Linton et al., 2013). Plywood is widely used as building material for houses as temporary housing because it is light and applicable (Islam, Khatun, \& Amin, 2016; Zea Escamilla \& Habert, 2015). But it is not safe in terms of tsunami risk reduction.

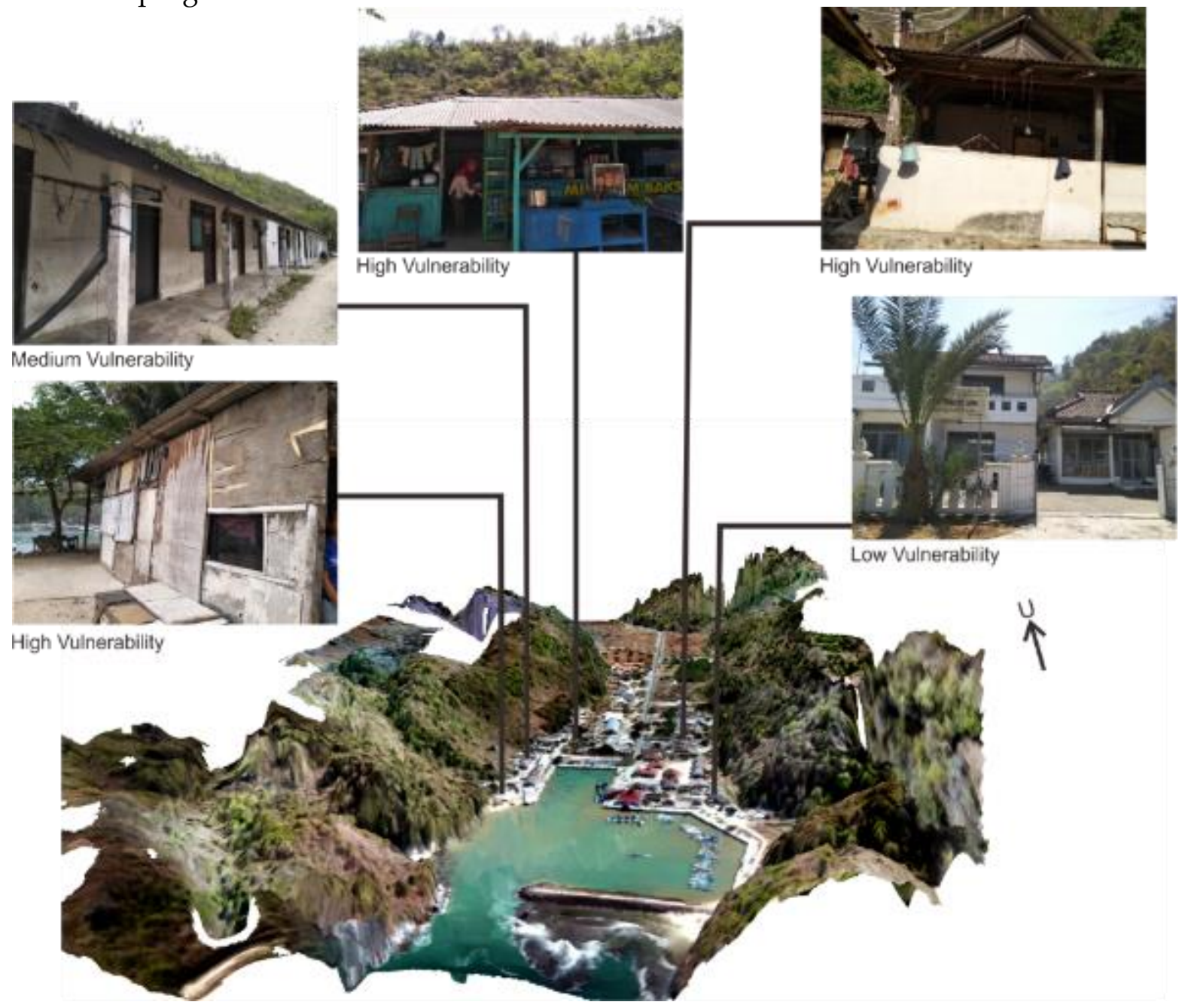

Figure 9. Buildings condition in Sadeng coastal area 
Source: research documentation, 2019

\section{Total Vulnerability}

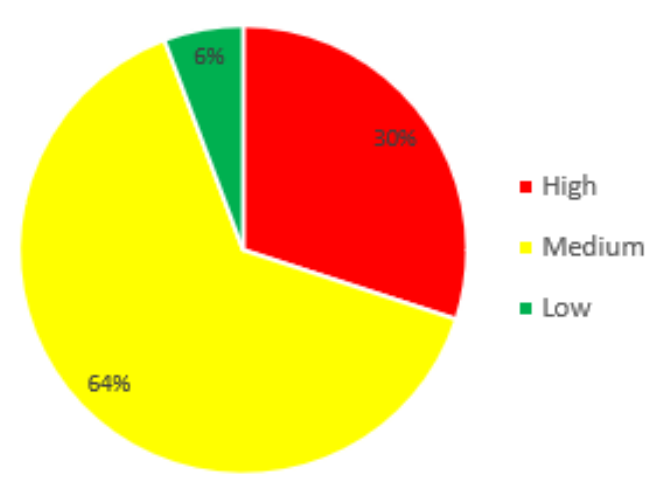

Figure 10. Percentage of tsunami vulnerability in Sadeng

(Source: Data analysis, 2020)

The total vulnerability was determined based on the social vulnerability and the building's physical vulnerability. The results showed that $64 \%$ of households classified as medium vulnerabilty, $30 \%$ of households classified as high vulnerability, and $6 \%$ of households classified as low vulnerability (Figure 10). Households with medium vulnerability were scattered in the western and eastern parts of the research location (Kesalahan! Sumber referensi tidak ditemukan.). Most of the households with medium vulnerability live in private houses and small portion of them live in government-owned houses. The building's physical vulnerability in this class were classified as medium and low vulnerability. Meanwhile, social characteristics in this class was dominated by ownership of current assets and high dependency ratio.

As much as $30 \%$ of households were categorized as high vulnerability. Households with high vulnerability were situated in the western part of this area. Based on building vulnerability, this area were highly vulnerable because the main material of the buildings were wood and plywood. In terms of social vulnerability, these households have high dependency ratio, low assets ownership, and high number of people in vulnerable group. 


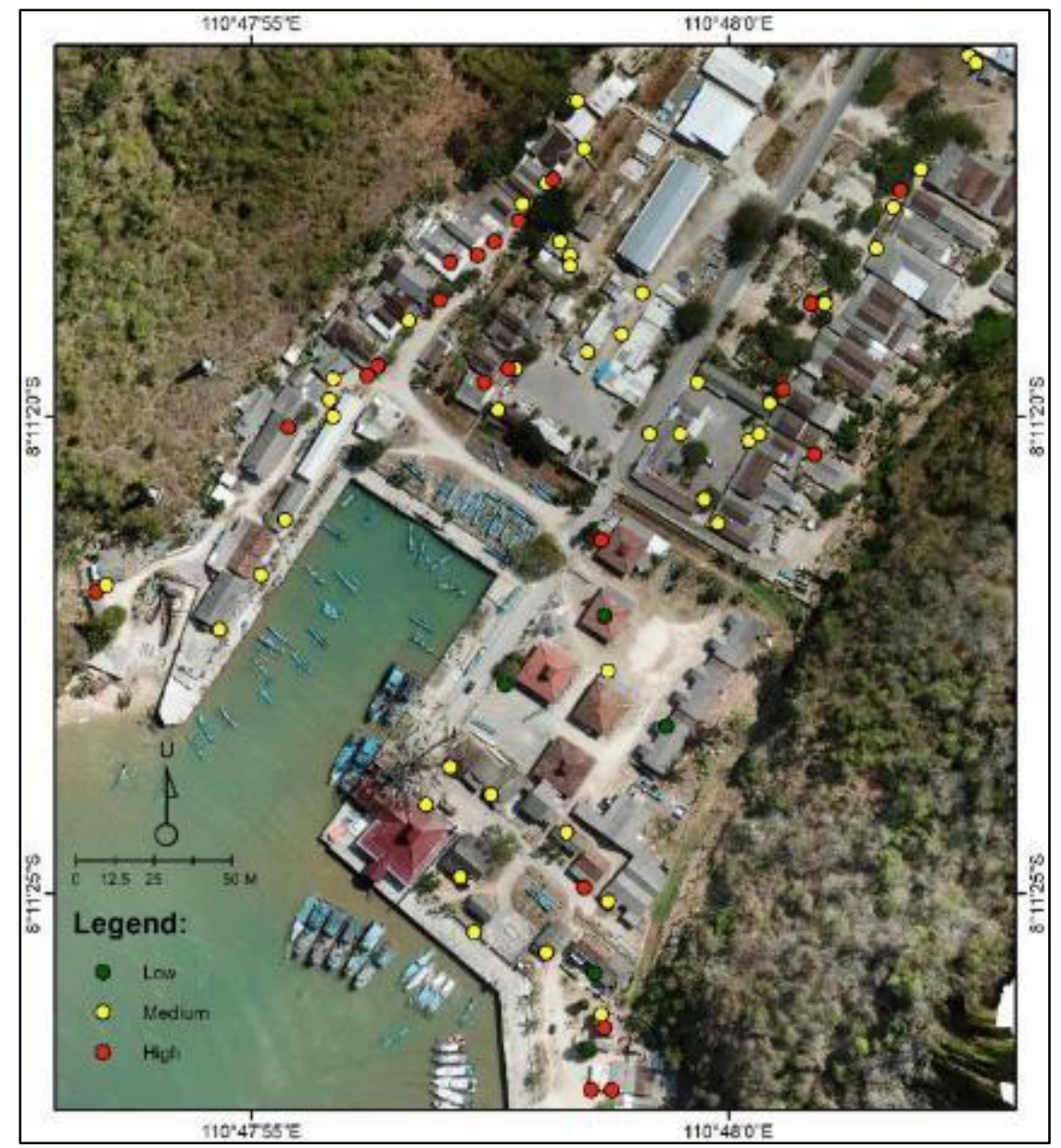

Figure 11. Household-based Total Vulnerability Map due to Tsunami

There was $6 \%$ of households classified as low vulnerability. These group live in government-owned buildings with a good quality so that building's physical vulnerability was low. Based on social vulnerability, these households were characterized by low dependency ratio, high assets ownership, and low number of people in vulnerable group. The physical strength of building combined with high economic capacity resulted in low vulnerabiltiy.

Physical and non-physical methods can be applied to reduce tsunami vulnerability. Phyisical method directly related to the bulding's physical vulnerability. Improving building's quality will directly reduce the vulnerability. Some steps include upgrade the main material of building and strengthen the building construction. Non-physical method purposed to reduce social vulnerability. Improving economic resilience through livelihood diversification and financial management for households can be the solution to reduce social vulnerability.

\section{CONCLUSION}

Households in Sadeng coastal area were catagorized as $64 \%$ of households in medium vulnerability, $30 \%$ of households in medium vulnerability, and $3 \%$ of households in low vulnerability. Spatial distribution of medium vulnerability households was evenly distributed throughout the study area. Physical and non-physical method can be applied to reduce tsunami vulnerability. Improving building's quality purposed to make the building more resistant to tsunami. Nonphysical methods focused on increasing economic capacity through livelihood diversification and financial management of households.

\section{ACKNOWLEDGEMENT}

Our gratitude goes to Research Institute of Universitas AMIKOM 
Yogyakarta for the funding, Mr. Triyanto as the head of Dukuh Gabukan, and students who have supported field survey and data collection.

\section{REFERENCES}

Adger, W. N. (2006). Vulnerability. Global Environmental Change, 16(3), 268-281. https://doi.org/10.1016/j.gloenvcha.2 006.02.006

Aerts, J. C. J. H., Botzen, W. J., Clarke, K. C., Cutter, S. L., Hall, J. W., Merz, B., ... Kunreuther, H. (2018). Integrating human behaviour dynamics into flood disaster risk assessment /704/242 /706/689/2788 /706/2805 perspective. Nature Climate Change, 8(3), 193-199. https://doi.org/10.1038/s41558-0180085-1

Aguirre-Ayerbe, I., Martínez Sánchez, J., Aniel-Quiroga, I., González-Riancho, P., Al-Yahyai, S., González, M., \& Medina, R. (2018). From tsunami risk assessment to disaster risk reduction The case of Oman. Natural Hazards and Earth System Sciences, 18(8), 2241-2260. https://doi.org/10.5194/nhess-182241-2018

Athukorala, P., \& Resosudarmo, B. P. (2005). The Indian Ocean Tsunami: Economic Impact, Disaster Management, and Lessons. Asian Economic Papers, 4(1), 139.

https://doi.org/10.1162/asep.2005.4.1. 1

Bakkensen, L. A., Fox-Lent, C., Read, L. K., \& Linkov, I. (2017). Validating Resilience and Vulnerability Indices in the Context of Natural Disasters. Risk Analysis, $\quad 37(5), \quad$ 982-1004. https://doi.org/10.1111/risa.12677

Birkmann, J., Cutter, S. L., Rothman, D. S., Welle, T., Garschagen, M., van Ruijven, B., ... Pulwarty, R. (2015). Scenarios for vulnerability: opportunities and constraints in the context of climate change and disaster risk. Climatic Change, 133(1), 53-68. https://doi.org/10.1007/s10584-0130913-2

BMKG. (2019). Katalog Tsunami Indonesia Tahun 416-2018: Per-Wilayah.
Chiaro, G., Kiyota, T., Pokhrel, R. M., Goda, K., Katagiri, T., \& Sharma, K. (2015). Reconnaissance report on geotechnical and structural damage caused by the 2015 Gorkha Earthquake, Nepal. Soils and Foundations, 55(5), 1030-1043. https://doi.org/10.1016/j.sandf.2015.0 9.006

Chmutina, K., \& von Meding, J. (2019). A Dilemma of Language: "Natural Disasters" in Academic Literature. International Journal of Disaster Risk Science, 10(3), 283-292. https://doi.org/10.1007/s13753-01900232-2

Cutter, S. L., Boruff, B. J., \& Shirley, W. L. (2003). Hazards, vulnerability and environmental justice. Social Science Quarterly, 84(2), 242-261. https://doi.org/10.4324/978184977154 2

Dall'Osso, F., Gonella, M., Gabbianello, G., Withycombe, G., \& Dominey-Howes, D. (2009). A revised (PTVA) model for assessing the vulnerability of buildings to tsunami damage. Natural Hazards and Earth System Sciences, 9, 1557-1565.

Dalrymple, R. A., \& Kriebel, D. L. (2005). Lesson in Engineering from the Tsunami in Thailand. The Bridge: Linking Engineering and Society, 35(2), 413.

https://doi.org/10.1109/TIGA.1967.41 80765

de León, J. C. V. (2008). Rapid Assessment of Potential Impacts of a Tsunami. Lessons from the Port of Galle in Sri Lanka. Source (Studies of the University: Research, Counsel, Education). Bonn.

De Risi, R., \& Goda, K. (2017). Probabilistic Earthquake-tsunami Hazard Assessment: The First Step Towards Resilient Coastal Communities. Procedia Engineering, 198(September 2016), 1058-1069. https://doi.org/10.1016/j.proeng.2017 .07 .150

Ghobarah, A., Saatcioglu, M., \& Nistor, I. (2006). The impact of the 26 December 2004 earthquake and tsunami on structures and infrastructure. 
Engineering Structures, 28(2), 312-326. https://doi.org/10.1016/j.engstruct.20 05.09.028

González-Riancho, P., Aguirre-Ayerbe, I., García-Aguilar, O., Medina, R., González, M., Aniel-Quiroga, I., ... Gavidia, F. (2014). Integrated tsunami vulnerability and risk assessment: Application to the coastal area of El Salvador. Natural Hazards and Earth System Sciences, 14(5), 1223-1244. https://doi.org/10.5194/nhess-141223-2014

Gregory, D., Johnston, R., Pratt, G., Watts, M. J., \& Whatmore, S. (Eds.). (2009). The dictionary of human geography. The dictionary of human geography. (5th ed.). West Sussex, England: Wiley Blackwell. https://doi.org/10.2307/633383

Hamzah, L., Puspito, N., \& Imamura, F. (2000). Tsunami Catalog and Zones in Indonesia. Journal of Natural Disaster Science, 22(1), 25-43. Retrieved from https://www.jstage.jst.go.jp/article/j nds/22/1/22_1_25/_pdf

Hizbaron, D. R., Hadmoko, D. S., Samodra, G., Dalimunthe, S. A., \& Sartohadi, J. (2010). Tinjauan Kerentanan, Risiko dan Zonasi Rawan Bahaya Rockfall di Kulonprogo, Yogyakarta. Forum Geografi2, 24(2), 119-136. https://doi.org/DOI:

https://doi.org/10.23917/forgeo.v24i2 .5021

Islam, S. M. Z., Khatun, D., \& Amin, A. (2016). A Study on the Structural Strength and Behaviour of Composite Profiled Steel Sheet with Plywood. Applied Mechanics and Materials, 860, 105-110.

https://doi.org/10.4028/www.scientif ic.net/amm.860.105

León, J., \& March, A. (2016). An urban form response to disaster vulnerability: Improving tsunami evacuation in Iquique, Chile. Environment and Planning B: Planning and Design, 43(5), 826-847.

https://doi.org/10.1177/026581351559 7229

Lindell, M. K., \& Prater, C. S. (2003).
Assessing community impacts of natural disasters. Natural Hazards Review, 4(4), 176-185. https://doi.org/10.1061/(ASCE)15276988(2003)4:4(176)

Linkov, I., Bridges, T., Creutzig, F., Decker, J., Fox-Lent, C., Kröger, W., ... ThielClemen, T. (2014). Changing the resilience paradigm. Nature Climate Change, 4(6), 407-409. https:/ / doi.org/10.1038/nclimate2227

Linton, D., Gupta, R., Cox, D., Van De Lindt, J., Oshnack, M. E., \& Clauson, M. (2013). Evaluation of tsunami loads on woodframe walls at full scale. Journal of Structural Engineering (United States), 139(8), 1318-1325. https:/ / doi.org/10.1061/(ASCE)ST.19 43-541X.0000644

Marfai, M. A., King, L., Singh, L. P., Mardiatno, D., Sartohadi, J., Hadmoko, D. S., \& Dewi, A. (2008). Natural hazards in Central Java Province, Indonesia: An overview. Environmental Geology, 56(2), 335-351. https://doi.org/10.1007/s00254-0071169-9

McEntire, D. (2011). Understanding and reducing vulnerability: From the approach of liabilities and capabilities. Disaster Prevention and Management: An International Journal, 20(3), 294-313. https://doi.org/10.1108/096535611111 41736

Moon, W. C., Chiew, L. Q., Cheong, K. W., Tee, Y. C., Chun, J. B., \& Lau, T. L. (2019). An experimental study for estimating tsunami wave forces acting on building with seaward and landward macroroughness. Ocean Engineering, 186(July 2018), 106116. https://doi.org/10.1016/j.oceaneng.20 19.106116

Nucifera, F., Riasasi, W., Putro, S. T., \& Marfai, M. A. (2019). Penilaian Kerentanan dan Kesiapsiagaan Bencana Tsunami di Pesisir Sadeng, Gunungkidul. Jurnal Geografi, 11(2), 182-192. https://doi.org/10.24114/jg.v11i2.114 75 
O'Brien, G., O'Keefe, P., Rose, J., \& Wisner, B. (2006). Climate change and disaster management. Disasters, 30(1), 64-80. https://doi.org/10.1111/j.14679523.2006.00307.x

Osaragi, T. (2002). Classification Methods for Spatial Data Representation (CASA Working Papers 40). London, UK. Retrieved from https://www.researchgate.net/public ation/32884891_Classification_method s_for_spatial_data_representation/link /53f483510cf2fceacc6e86d2/download

Reese, S., Cousins, W. J., Power, W. L., Palmer, N. G., Tejakusuma, I. G., \& Nugrahadi, S. (2007). Tsunami vulnerability of buildings and people in South Java - Field observations after the July 2006 Java tsunami. Natural Hazards and Earth System Science, 7(5), 573-589. https://doi.org/10.5194/nhess-7-5732007

Sawai, M. (2011). Who is Vulnerable During Tsunamis? Experiences From the Great East Japan Earthquake 2011 and the Indian Ocean Tsunami 2004. UN Economic and Social Commission for Asia and the Pacific, 1-19.

Shah, A. A., Ye, J., Abid, M., Khan, J., \& Amir, S. M. (2018). Flood hazards: household vulnerability and resilience in disaster-prone districts of Khyber Pakhtunkhwa province, Pakistan. Natural Hazards, 93(1), 147-165. https://doi.org/10.1007/s11069-0183293-0

Shapira, S., Aharonson-Daniel, L., \& BarDayan, Y. (2018). Anticipated behavioral response patterns to an earthquake: The role of personal and household characteristics, risk perception, previous experience and preparedness. International Journal of Disaster Risk Reduction, 31(January), 18.

https://doi.org/10.1016/j.ijdrr.2018.04 .001

Stăngă, I. C., \& Grozavu, A. (2012). Quantifying human vulnerability in rural areas: Case study of Tutova Hills (Eastern Romania). Natural Hazards and
Earth System Science, 12(6), 1987-2001. https://doi.org/10.5194/nhess-121987-2012

Tinti, S., Tonini, R., Bressan, L., Armigliato, A., Gardi, A., Guillande, R., ... Scheer, S. (2011). Handbook of Tsunami Hazard and Damage Scenarios. (JRC-IPSC, Ed.). Bologna: JRC-IPSC. https://doi.org/10.2788/21259

Tomiczek, T., Prasetyo, A., Mori, N., Yasuda, T., \& Kennedy, A. (2017). Effects of a macro-roughness element on tsunami wave amplification, pressures, and loads: Physical model and comparison to Japanese and US Design Equations. Coastal Engineering Journal, 59(1). https://doi.org/10.1142/S0578563417 500048

UNESCO. (2015). Tsunami Risk Assessment and Mitigation for the Indian Ocean: knowing your tsunami risk-and what tod o about it. IOC MAnualas and Guides No. 52 (Second). Paris.

UNISDR. (2009). 2009 UNISDR Terminology on Disaster Risk Reduction. Geneva: UNISDR.

https://doi.org/10.4324/978135113844 4-36

United Nation. (2015). Sendai Framework for Disaster Risk Reduction 2015-2030. Framework for Disaster Risk Reduction. Sendai. Retrieved from https://www.preventionweb.net/files /43291_sendaiframeworkfordrren.pdf

United Nations. (2015). Infrastructure and Disaster. In Conference on DIsaster Risk Reduction. Sendai: United Nations. Retrieved from https://www.preventionweb.net/files /40429_infrastructure.pdf

Vatsa, K. S. (2004). Risk, Vulnerability, and Asset-based Approach to Disaster Risk Management. International Journal of Sociology, 24(10), 1-48.

Wibowo, T. W., Mardiatno, D., \& Sunarto. (2017). Pemetaan Risiko Tsunami terhadap Bangunan secara Kuantitatif. Majalah Geografi Indonesia, 31(2), 68-78. https://doi.org/DOI: https://doi.org/10.22146/mgi.25493 
Wisner, B., Blaikie, P., Cannon, T., \& Davis, I. (2004). At Risk: Ntural hazards, people vulnerability and disasters. Feuillets de Radiologie (Second, Vol. 43). New York: Routledge. Taylor \& Francis Group. Retrieved from http://ovidsp.ovid.com/ovidweb.cgi? $\mathrm{T}=\mathrm{JS} \& \mathrm{PAGE}=$ reference $\& \mathrm{D}=$ emed $6 \& \mathrm{~N}$ EWS $=N \& A N=2003372014$

Yang, S., He, S., Du, J., \& Sun, X. (2015). Screening of social vulnerability to natural hazards in China. Natural Hazards, $\quad 76(1), \quad$ 1-18. https://doi.org/10.1007/s11069-0141225-1

Yoon, D. K. (2012). Assessment of social vulnerability to natural disasters: A comparative study. Natural Hazards, 63(2), 823-843. https://doi.org/10.1007/s11069-0120189-2

Yoon, Dong Keun, \& Jeong, S. (2016). Assessment of Community Vulnerability to Natural Disasters in Korea by Using GIS and Machine Learning Techniques. In E. Kim \& B. H. S. Kim (Eds.), Assessment of Community Vulnerability to Natural Disasters in Korea by Using GIS and Machine Learning Techniques (pp. 123-140). Singapore: Springer. https://doi.org/10.1007/978-981-100300-4

Zea Escamilla, E., \& Habert, G. (2015). Global or local construction materials for postdisaster reconstruction? Sustainability assessment of twenty post-disaster shelter designs. Building and Environment, 92, 692-702. https://doi.org/10.1016/j.buildenv.20 15.05.036

Zhou, Y., Li, N., Wu, W., Wu, J., \& Shi, P. (2014). Local spatial and temporal factors influencing population and societal vulnerability to natural disasters. Risk Analysis, 34(4), 614-639. https://doi.org/10.1111/risa.12193 